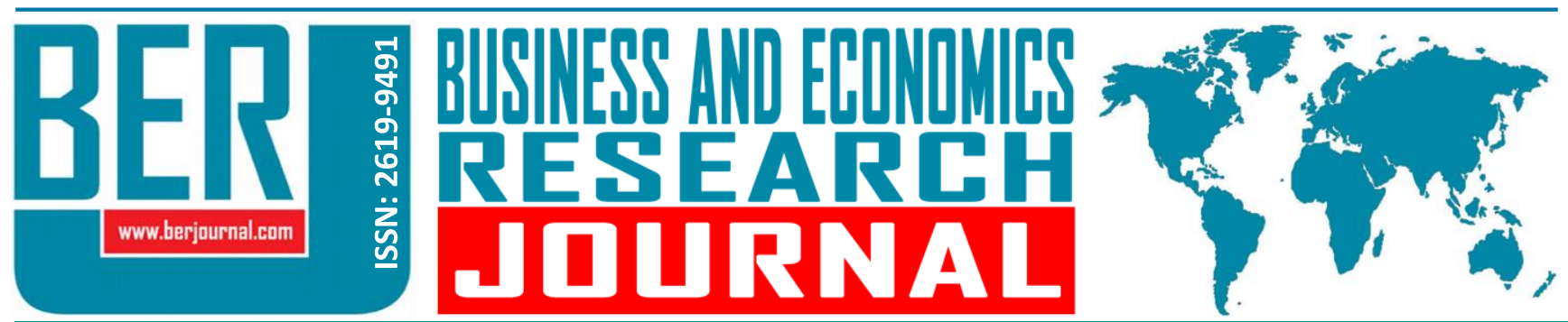

Business and Economics Research Journal Vol. 11, No. 2, 2020, pp. 335-351 doi: 10.20409/berj.2020.253

\title{
Savunma Harcamaları ve Ekonomik Büyüme İlişkisi: Türkiye Örneği
}

\author{
Ceylan Karakaya ${ }^{a}$, Tuba Sahinoglu ${ }^{b}$
}

Öz: Savunma harcamaları, ülkenin iç ve dış güvenliğini sağlamak adına önemli bir faktördür. Farklı ülkelerin veya bölgelerin birbirleri için oluşturdukları tehditler ülkelerin savunma harcamalarını artırmalarına neden olmaktadır. Bunun sonucunda ulusal egemenliği korumak amacıyla gerçekleştirilen savunma harcamalarının ülke ekonomisi üzerinde de önemli etkileri bulunmaktadır. Dolayısıyla çalışmanın amacını, Türkiye ekonomisi için savunma harcamaları ile ekonomik büyüme arasındaki ilişkinin incelenmesi oluşturmaktadır. Bu amaçla, 1984-2016 dönemine ait yıllık veriler kullanılarak Türkiye'de savunma harcamalarının ekonomik büyüme üzerindeki etkisinin varlığı ve yönü, ARDL Sınır Testi ve Johansen Eşbütünleşme Testi yöntemleri kullanılarak araştırılmıştır. Ayrıca analize teknolojik gelişme değişkeni de dâhil edilmiştir. Johansen eşbütünleşme testi sonuçları Türkiye ekonomisi için ele alınan değişkenler arasında uzun dönemde negatif yönlü bir ilişkinin varlığına işaret etmektedir. ARDL sınır testi sonuçları ise uzun ve kısa dönemde hem savunma harcamaları hem de teknolojik değişmenin ekonomik büyüme üzerinde pozitif yönde bir etkiye sahip olduğunu göstermektedir. Diğer yandan Granger nedensellik testi sonuçlarına göre savunma harcamaları ile ekonomik büyüme arasında çift yönlü bir nedensellik ilişkisi vardır.

\section{The Relationship between Defense Spending and Economic Growth: The Case of Turkey}

\begin{abstract}
Defense spending is an important factor in ensuring the internal and external security of the country. The threats created by different countries or regions for each other cause them to turn to defense spending. Defense expenditures which are carried out to protect national security, have significant effects on the national economy as well. Therefore, the aim of working is to examine the relationship between defense spending and economic growth for Turkish economy. For this purpose, the presence and direction of the impact of defense spending on economic growth in Turkey, was investigated using the 1984-2016 annual data by ARDL (Autoregressive Distributed Lag Model) Bounds Test and Johansen Cointegration Test. Technological development variable is also included in the analysis. Johansen cointegration test results suggests the existence of a negative relationship in the long term for Turkey's economy. The results of ARDL bounds test show that both defense expenditures and technological change have a positive effect on economic growth in the long and short term. On the other hand, according to Granger causality test results, there is a bidirectional causality relationship between defense expenditures and economic growth.
\end{abstract}

\author{
Anahtar Sözcükler: Kamu \\ Harcamaları, Savunma \\ Harcamaları, Ekonomik \\ Büyüme, ARDL Sınır Testi, \\ Johansen Eşbütünleşme \\ Testi \\ JEL: C32, H56, $\mathrm{O} 38$

$\begin{array}{ll}\text { Geliş } & : \text { 11 Eylül } 2019 \\ \text { Düzeltme } & : \text { 13 Kasım } 2019 \\ \text { Kabul } & : \text { 30 Ocak } 2020 \\ \text { Tür } & : \text { Araştırma }\end{array}$

Keywords: Public Expenditures, Defense Expenditures, Economic Growth, ARDL Bounds Test, Johansen Cointegration Test

JEL: C32, H56, O38

Received : 11 September 2019

Revised : 13 November 2019

Accepted : 30 January 2020

Type : Research

a Graduate Student, Ataturk University, Institute of Social Sciences, Department of Economics, Erzurum, Turkiye, ceylankarakaya8912@gmail.com (ORCID ID: 0000-0002-2483-0151)

b Asst. Prof., PhD., Ataturk University, Faculty of Economics and Administrative Sciences, Department of Economics, Erzurum, Turkiye, tsahinoglu@atauni.edu.tr (ORCID ID: 0000-0002-5742-247X) 


\section{Giriş}

Farklı ülkelerin veya bölgelerin birbirleri için oluşturdukları tehditler ülkelerin savunma harcamalarına yönelmelerine neden olmaktadır. Dolayısıyla ülkelerin hâkimiyetlerini ve bağımsızlıklarını sağlamak için savunma hizmetlerini güçlendirmeleri gerekmektedir. Savunmanın sağlanması beklenmedik durumları ve belirsizlikleri karşılamak için kaynak tahsisi gerektiren önemli bir faaliyettir. Bu nedenle savunma hizmetlerinin karşılanabilmesi için devletler bütçelerinden savunma harcamalarına yönelik olarak bir miktar pay ayırmaktadır.

Milli güvenliğin sağlanması ve bu amaçla gerçekleştirilen savunma harcamaları ülke ekonomisi açısından da büyük önem taşımaktadır. Zira güvenli bir ortamın sağlanması ekonomik büyümenin gerçekleştirmesinde önemli bir olgudur. Diğer yandan savunma harcamaları, bütçe içindeki payının yüksek olması ve önemli bir GSYH bileşeni olması itibariyle de ekonomik büyüme üzerinde ciddi bir etkiye sahiptir.

Ülkeler arasında artan rekabet, ülke ekonomilerinde meydana gelen yenilikler ve gelişmeler ile birlikte ekonomik büyümenin belirleyicileri de zaman içerisinde değişikliğe uğramaktadır. Daha öncesinde askeri harcamaların daha verimli harcamalar ve sivil yatırımları dışladığı ve dolayısıyla ekonomik büyümeyi olumsuz yönde etkilediği yönünde görüş hâkim iken Benoit (1978), yüksek savunma harcamalarının büyümeyi teşvik ettiği yönündeki yaklaşımı ile söz konusu ilişkiye farklı bir bakış açısı sunmuştur. Eğitim, sağlık ve diğer sosyal-ekonomik faaliyetlerdeki yatırım ve harcamaların eksik olması, ekonomik büyümeyi olumsuz etkileyeceğinden kamu kaynaklarının savunma harcamalarına ayrılacak miktarın ve ekonomik büyüme üzerindeki etkisinin analiz edilmesi önem taşımaktadır (Hou ve Chen, 2013).

Gelişmekte olan ülkelerde özellikle gelişme aşaması, ülkenin komşu ülkelerle olan ilişkisi, ülkede silah endüstrisinin varlığı ve siyasi yapısına göre askeri harcamaların düzeyi değişmektedir (Dunne ve Tian, 2013). Türkiye bulunduğu konum itibariyle ve Ortadoğu'da yaşanan istikrarsızlıklar nedeniyle yüksek risk altındadır. Tehdit düzeyinin arttığı ve ekonomik göstergelerin sürekli değiştiği Türkiye'de savunma harcamaları ve ekonomik büyüme arasındaki ilişkinin incelenme gerekliliği daha da artmaktadır.

Bu doğrultuda çalışmanın amacı Türkiye'de savunma harcamalarının ekonomik büyüme üzerindeki etkisinin varlığının ve yönünün araştırılmasıdır. Savunma harcamaları-büyüme ilişkisini tahmin etmek için Johansen Eşbütünleşme Testi, ARDL Sınır Testi ve Granger Nedensellik Testinin kullanıldığı ampirik analizde 1984-2016 dönemine ilişkin yıllık veriler dikkate alınmıştır. Savunma harcamalarına ek olarak, büyüme ve savunma harcamaları üzerinde önemli bir etkiye sahip olduğu düşünülen teknolojik değişiminde modele dâhil edilmesi nedeniyle çalışmanın bu konuya ilişkin literatüre katkı sağlaması beklenmektedir.

Çalışmada öncelikle savunma harcamaları tanımlanarak kapsamı ifade edilmiştir. Ardından savunma harcamaları ile ekonomik büyüme arasındaki ilişki literatürde yer alan görüşler ışığında irdelenmiş ve konuya ilişkin ampirik literatüre yer verilmiştir. Çalışmanın geri kalan kısmında Türkiye'de savunma harcamalarının geçmişi tablolar yardımıyla sunulmuştur. Sonrasında ampirik analizde kullanılan yöntem, veriler ve model başlıklarına yer verilerek bu analizden elde edilen sonuç ve öneriler açıklanmıştır.

\section{Savunma Harcamaları}

Savunma harcamaları ülkelerin, egemenliği ve ulusal varlığının devamlılığı, iç ve dış güvenliğinin sağlanması için milli gelirden savunmaya ayırdıkları pay (Aksoğan, Taş ve Örnek, 2013: 661) olarak tanımlanmaktadır. Başar ve Künü (2012)'ye göre ise "savunma harcamaları; savunma hizmetinde kullanılan araç ve gereçlerin üretilmesi veya satın alınması, bakım ve onarımlarının yapılması, araştırma ve geliştirme faaliyetlerinin geçekleştirilmesi, tahsis edilmiş askeri ve sivil personel ile ilgili harcamaların yapılması gibi ana başlıklardan oluşmaktadır".

Ülkeler, kendilerine karşı yapılacak bir saldırının caydırılması ve olabilecek herhangi bir saldırıya karşı ülkeyi korumak amacı ile savunma harcaması yapmaktadır. Ayrıca tam kamusal mal olma özelliğinden ötürü savunma hizmeti "bölünmez fayda" sağlamaktadır. Dolayısıyla ülkede yaşayan bütün fertler savunma hizmetinden birbirine rakip olmadan eşit bir şekilde faydalanmaktadır. Diğer yandan ülkenin her yerinde savunmanın sağladığı fayda homojen dağılmakta ve herhangi bir karşılık ödemeyenler dahi bu hizmetten 
yararlanmaktadır. Bu da savunma hizmetinin tüketiminde herhangi bir dışlamanın olmamasının bir göstergesidir (Erbaykal, 2007: 3).

Tablo 1. NATO, IMF ve BM 'nin Savunma Harcamalarına İlişkin Tanımları ve Savunma Harcaması Kalemleri

\begin{tabular}{|c|c|c|c|c|}
\hline & Savunma, Güç ve Destekçileri İ̧̧in Yapılan Harcamalar & & & \\
\hline & & NATO & IMF & BM \\
\hline 1 & Asker ve görevli (personel) ödemeleri & $\mathrm{x}$ & $\mathrm{X}$ & $\mathrm{x}$ \\
\hline 2 & Askeri organizasyonlarla ilgili veya ordu içindeki teknisyen, bürokrat vs. ücretleri & & & \\
\hline & & $\mathrm{x}$ & $\mathrm{x}$ & $\mathrm{x}$ \\
\hline 3 & Tıbbi hizmetler, vergisel ayrıcalıklar ve sosyal faydalar (Akrabalar dâhil) & $\mathrm{x}$ & $\mathrm{x}$ & $\mathrm{x}$ \\
\hline 4 & Emeklilik maaşı & $\mathrm{x}$ & - & $\mathrm{x}$ \\
\hline 5 & Askeri okullar, hastaneler vb. & $\mathrm{X}$ & $\mathrm{X}$ & $?$ \\
\hline 6 & Silah harcamaları (ithal silahlar dâhil) & $\mathrm{X}$ & $\mathrm{X}$ & $\mathrm{X}$ \\
\hline 7 & Altyapı yatırımları, binalar vb. & $\mathrm{X}$ & $\mathrm{X}$ & $\mathrm{X}$ \\
\hline 8 & Bakım ve onarım & $\mathrm{x}$ & $\mathrm{x}$ & $\mathrm{x}$ \\
\hline 9 & Diğer malların tedariki & $\mathrm{x}$ & $\mathrm{x}$ & $\mathrm{X}$ \\
\hline 10 & Askeri araştırma ve geliştirme & $\mathrm{X}$ & $\mathrm{X}$ & $\mathrm{X}$ \\
\hline & Askeri/Savunma/Stratejik Amaçlarla ilgili Diğer Harcamalar & & & \\
\hline 11 & Stratejik malların stoklanması & $x^{b}$ & - & - \\
\hline 12 & Silah ve üretim yerleri vb. korumak & $x^{b}$ & $\mathrm{X}$ & - \\
\hline 13 & $\begin{array}{l}\text { Silah üretim sübvansiyonları/Değişim } \\
\text { Sübvansiyonları }\end{array}$ & $\mathrm{X}$ & - & - \\
\hline 14 & Diğer ülkelere yapılan askeri yardımlar & $\mathrm{x}$ & $\mathrm{x}$ & $\mathrm{x}$ \\
\hline 15 & $\begin{array}{l}\text { Uluslararası organizasyonlara katkılar } \\
\text { (Askeri anlaşmalar, Birleşmiş Milletler } \\
\text { Barışın korunması vb.) }\end{array}$ & $x$ & $x$ & - \\
\hline 16 & Sivil savunma & - & $\mathrm{x}$ & $\mathrm{X}$ \\
\hline & Eski Askeri Güçler/Faaliyetlere Yapılan Harcamalar & & & \\
\hline 17 & Gazilere sağlanan menfaatler vb. & - & - & - \\
\hline 18 & Savaş borçları & - & - & - \\
\hline & Güçlere Yapılan Harcamalar & & & \\
\hline 19 & Orduya bağlı olmayan güçler/Jandarma gücü & $x^{c}$ & $\mathrm{X}^{\mathrm{c}}$ & $x^{c}$ \\
\hline 20 & Sınırlar/Gümrük muhafızları & $X^{c}$ & $x^{c}$ & $x^{c}$ \\
\hline 21 & Polis idaresi & $x^{c}$ & - & - \\
\hline & Diğer Hesaplardaki Harcamalar & & & \\
\hline 22 & Yardım/Felaketten kurtarma & $\mathrm{x}$ & - & - \\
\hline 23 & Birleşmiş Milletler Barışı Koruma & $\mathrm{X}$ & $x$ & - \\
\hline & Gelecek Harcamalar İçin Yükümlülükler & $\mathrm{X}$ & $\mathrm{x}$ & - \\
\hline 24 & Kredi temini & & & \\
\hline
\end{tabular}

Kaynak: Brzoska, 1995: $48-49$ (Aktaran; Filiz Giray, 2004: 184-185).

a Semboller: X: Savunma harcamalarına dahil, - : Savunma harcamalarına dahil değil.

b Eğer savunma organizasyonu tarafından yönetiliyor ve finanse ediliyorsa.

c Askeri faaliyetler için eğitilip, donatıldığı ve mevcut olduğu hükmü verildiği zaman.

Diğer yandan savunma harcamalarına yapılan tanımlarda tam olarak bir fikir birliğine ulaşılamamıştır. Yapılan çalışmaların birçoğunda savunma harcamalarının standart bir tanımının olmadığı ileri sürülmektedir. Bunun nedeni, savunma harcamalarının tanımı, kapsamı, niteliği ve savunma kalemlerinin ülkeden ülkeye değişiklik göstermesidir. Savunma harcamaları için yapılan tanımların farklılık göstermesi ise savunma harcamalarının farklı hesaplanmasına yol açmaktadır (Durgun ve Timur, 2014: 127). Benzer biçimde uluslararası kuruluşlarda da ortak bir tanım oluşturulmamıştır. NATO, IMF ve BM 'nin savunma harcamalarına ilişkin yapmış olduğu tanımlar Tablo 1'de yer almaktadır. Bu tabloya göre uluslararası karşılaştırmalar yapmak amacıyla kullanılabilecek en kapsamlı ve en uygun tanım Birleşmiş Milletler (BM)'ne ait olandır. 


\subsection{Türkiye'de Savunma Harcamalarının Geçmişi ve Niteliği}

Ülkeler algıladıkları tehditler, terör olaylarının yoğunluğu ve istikrarsızlıkların varlığına göre bütçelerinden savunma harcamalarına pay ayırdıklarından savunma harcamalarının düzeyi bakımından ülkeler arasında önemli farklar bulunmaktadır. Bu nedenle yapılan savunma harcamalarının boyutunun, ülkelerin algıladıkları risk derecesine bağlı olduğu ifade edilebilir. Bilindiği üzere Türkiye sosyal çıkarların çatıştığı, ekonomik ve siyasal istikrarsızlıkların yaşandığı ve bölgesel karışıklıkların yoğun olduğu bir coğrafyada bulunmaktadır. Dolayısıyla bu etkenler savunma harcamalarının artmasını etkileyen faktörler arasında yer almaktadır. Türkiye'de savunma harcamalarının yüksek olmasının bir diğer nedeni de NATO'da ABD'den sonra sayısal olarak ikinci en büyük, Avrupa'da ise en büyük orduya sahip olmasıdır (Erbaykal, 2007: 68). Güncel olaylar ele alınacak olursak Ortadoğu'da yaşanan olayların Türkiye için büyük bir risk oluşturması, komşu ülkelerde devam eden terör olayları ve Suriye ve Irak'ta yaşanan istikrarsızlıklar Türkiye'de savunma hizmetlerinin önemini artırmaktadır (Üçler, 2017: 62). Şekil 1'de son 10 yılda savunma harcamalarının seyri incelendiğinde genel olarak artış eğilimi gösterdiği, özellikle 2005 yılı sonrası söz konusu artışın hızlandığı görülmektedir.

Şekil 1. 2008-2018 Döneminde Türkiye'de Savunma Harcamaları (2017 Fiyatlarıyla, Milyon ABD Doları)

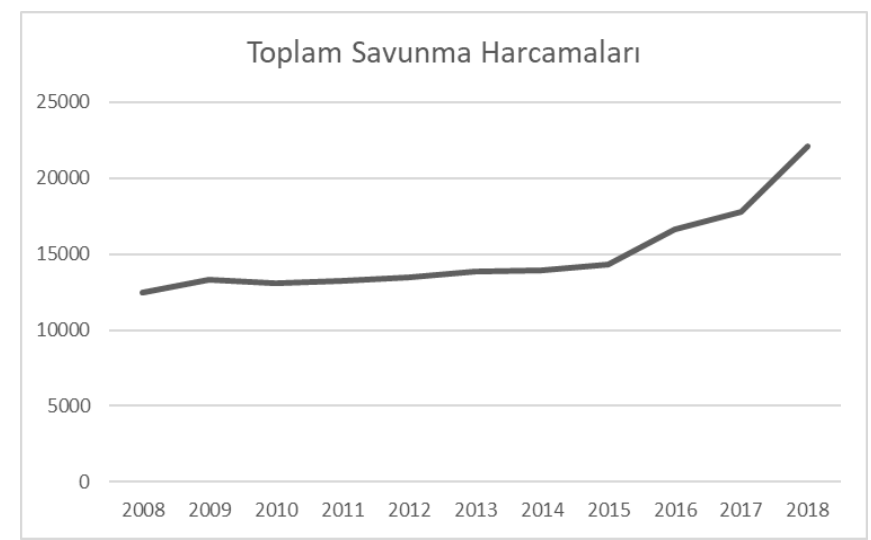

Kaynak: SIPRI Military Expenditure Database.

İkinci Dünya Savaşı'ndan sonra gelişen teknoloji ile birlikte silah üretiminin artması dünyanın birçok ülkesinde savunma harcamalarının yükselmesine yol açmıştır. 1960'lı yıllarda Türkiye de dünyanın pek çok ülkesinde olduğu gibi silahlanma yarışından etkilenmiştir (Aksoğan vd., 2013: 667). 1970'li yıllarda Türkiye savunma sanayine önemli miktarda kaynak ayırmış ve 1974 Kıbrıs Barış Harekâtı bu harcamayı tetikleyen önemli bir faktör olmuştur. Bu dönemde Türkiye, savunma sanayi alanında en çok harcamaya sahip Kuzey Atlantik Anlaşması Örgütü (NATO) ülkesi konumuna gelmiştir.

1980 'li yıllara gelindiğinde ulusal silah sanayini kullanarak silah donanımının geliştirilmesi amacıyla Türk Silahlı Kuvvetleri'nin Modernizasyonu Programı yürürlüğe girmiştir. Modernizasyon programı ile savunma sanayinin bütçedeki payı artmaya, milli bir savunma sanayii oluşturulması yönündeki çalışmalar hızlanmaya ve savunma sanayi alanında önemli yatırımlar yapılmaya başlanmıştır. Soğuk savaşın sona erdiği 1990 'lı yıllarda NATO ülkelerindeki savunma harcamalarında genellikle bir düşüş olduğu gözlemlenirken, Türkiye için bu düşüş eğilimi gerçekleşmemiştir (Aksoğan vd., 2013: 667-668).

Günümüz ekonomisinde savunma harcamalarına ayrılan pay önemini korumaktadır. SIPRI (Stockholm Uluslararası Barış Araştırmaları Enstitüsü) raporlarına göre 2017 yııında dünya askeri harcamaları toplamı 1,74 trilyon ABD Dolarıdır (The SIPRI Military Expenditure Database, 2017). Rapor sonuçlarına yer verilen Tablo 2'ye göre en fazla savunma harcaması yapan 15 ülke arasında 610 milyar ABD Doları ile birinci sırada ABD yer almaktadır. ABD'yi sırasıyla 228 milyar ABD Doları ile Çin ve 69,4 milyar ABD Dolarıyla Suudi Arabistan izlemektedir. Türkiye ise 18,2 milyar ABD Doları ile sıralamada 15. sırada yer almaktadır. 
C. Karakaya - T. Sahinoglu

Tablo 2. Toplam Savunma Harcamalarına Göre Sıralamadaki Illk 15 Ülke

\begin{tabular}{|c|c|c|c|c|c|c|c|}
\hline \multicolumn{2}{|c|}{ Siralama } & \multirow[b]{2}{*}{ Ülke } & \multirow[b]{2}{*}{$\begin{array}{l}\text { Toplam } \\
\text { Savunma } \\
\text { Harcaması } \\
\text { (Milyar \$) }\end{array}$} & \multirow[b]{2}{*}{$\begin{array}{l}\text { 2008-2017 } \\
\text { Döneminde } \\
\text { \% Değişim }\end{array}$} & \multirow[b]{2}{*}{$\begin{array}{l}\text { Dünyadaki } \\
\text { Payı } \\
\text { 2017(\%) }\end{array}$} & \multicolumn{2}{|c|}{$\begin{array}{c}\text { Savunma } \\
\text { Harcamalarının } \\
\text { GSYH İçindeki \% Payı }\end{array}$} \\
\hline 2017 & 2016 & & & & & 2017 & 2008 \\
\hline 1 & 1 & ABD & 610 & -14 & 35 & 3,1 & 4,2 \\
\hline 2 & 2 & Çin & 228 & 110 & 13 & 1,9 & 1,9 \\
\hline 3 & 4 & Suudi Arabistan & 69,4 & 34 & 4 & 10 & 7,4 \\
\hline 4 & 3 & Rusya & 66,3 & 36 & 3,8 & 4,3 & 3,3 \\
\hline 5 & 6 & Hindistan & 63,9 & 45 & 3,7 & 2,5 & 2,6 \\
\hline 6 & 5 & Fransa & 57,8 & 5,1 & 3,3 & 2,3 & 2,3 \\
\hline 7 & 7 & İngiltere & 47,2 & -15 & 2,7 & 1,8 & 2,3 \\
\hline 8 & 8 & Japonya & 45,4 & 4,4 & 2,6 & 0,9 & 0,9 \\
\hline 9 & 9 & Almanya & 44,3 & 8,8 & 2,5 & 1,2 & 1,3 \\
\hline 10 & 10 & Güney Kore & 39,2 & 29 & 2,3 & 2,6 & 2,6 \\
\hline 11 & 13 & Brezilya & 29,3 & 21 & 1,7 & 1,4 & 1,4 \\
\hline 12 & 11 & italya & 29,2 & -17 & 1,7 & 1,5 & 1,7 \\
\hline 13 & 12 & Avusturalya & 27,5 & 33 & 1,6 & 2,0 & 1,8 \\
\hline 14 & 14 & Kanada & 20,6 & 13 & 1,2 & 1,3 & 1,2 \\
\hline \multirow[t]{3}{*}{15} & 15 & Türkiye & 18,2 & 46 & 1,0 & 2,2 & 2,2 \\
\hline & & 15 Ülke Toplamı & 1396 & - & 80 & & - \\
\hline & & Dünya Toplamı & 1739 & 9,8 & 100 & 2,2 & 2,4 \\
\hline
\end{tabular}

Kaynak: SIPRI Military Expenditure Database.

Şekil 2. 2017 yılında Savunma Harcamaları Sıralamasındaki ilk 15 Ülkenin Dünyadaki \% Payı

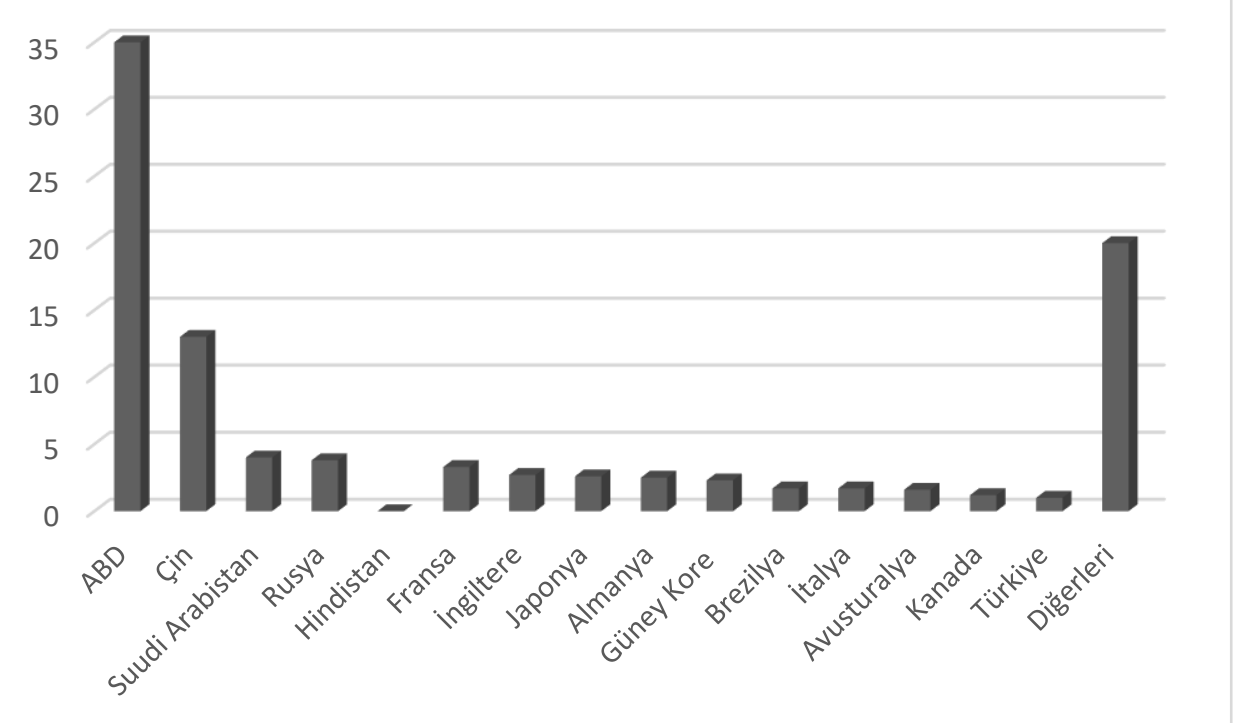

Kaynak: SIPRI Military Expenditure Database. 
Ülkelerin savunma harcamaları değerlendirilirken savunma harcamalarının dünyadaki yüzde payı önemli bir bilgi sunmaktadır. Şekil 2'de 2017 yılında savunma harcamaları sıralamasındaki ilk 15 ülkenin dünyadaki \% payı görülmektedir. Söz konusu değere bakıldı̆ı̆nda \%35 değerle ABD birinci sırada yer almaktadır. ABD'yi sırasıyla \%13 ile Çin, \%4 ile Suudi Arabistan izlemektedir. Türkiye ise \% 1'lik bir pay ile sıralamayı takip etmektedir. Askeri harcamaların 2008-2017 dönemindeki \% değişimi dikkate alındığında Türkiye'de \%46 oranında artış gözlemlenirken \%110 oranı ile Çin rekor bir artış yaşamıştır. ABD'de ise en yüksek askeri harcama yapan ülke olmasına karşın \%14 oranında düşüş olmuştur.

\subsection{Savunma Harcamaları ile Ekonomik Büyüme Arasındaki iliş̧ki}

Ülke insanının yaşam standartlarının iyileştirilmesi ve toplumsal refahın artırımasının tek yolu ekonomik büyümeden geçmektedir (Erbaykal, 2007: 27). Ekonomik büyüme genel olarak üretim faktörlerinin fert başına bir yıldan diğer yıla göre çıktıdaki artış miktarı şeklinde tanımlanmaktadır (Durgun ve Timur, 2017: 129). Büyümeden söz edebilmek için tasarruf, sermaye, nüfus ve milli gelir gibi büyüme göstergelerindeki artışların nominal olarak değil reel anlamda artması gerekmektedir (Demir ve Tanyıldız, 2017: 92). Kaynak (2014)'e göre "ekonomik büyüme, bir ülkede, belli bir dönemde (genellikle bir yıl) yerli ve yabancı herkes tarafından piyasada üretilen tüm nihai mal ve hizmetlerin parasal ifadesi olan GSYH (Gayrisafi Yurtiçi Hâsıla)'da ya da GSMH (Gayrisafi Milli Hâsıla)'da görülen artışa denir".

Ekonomik büyüme ve savunma harcamaları arasındaki ilişki, özellikle Benoit'in (1973a; 1978b) öncül çalışmasının ardından popüler hale gelmiştir. Söz konusu çalışma savunma harcamalarının ekonomik büyüme üzerinde olumlu bir etkiye sahip olduğunu vurgular niteliktedir. Sonrasında savunma ekonomisinin hem yurt içinde hem de uluslararası düzeyde istihdam, çıktı ve ekonomik büyüme gibi makroekonomik değişkenler üzerindeki etkisi teorik ve ampirik olarak birçok çalışmaya konu olmuştur. Ancak ekonomistler savunma harcamaları ve ekonomik büyüme arasındaki ilişki konusunda ortak bir sonuca ulaşamamışlardır (Ismail, 2017: 319).

Genel olarak savunma harcamaları ile ekonomik büyüme arasındaki ilişki iki teorik yaklaşım ile açıklanmaktadır. Bu yaklaşımlardan ilki savunma ile ekonomik büyüme arasındaki ilişkinin pozitif yönde olduğunu savunan Keynesyen Yaklaşım Teorisi'dir (Erbaykal, 2007: 43). Keynesyen Yaklaşım Teorisi'ne göre daha fazla savunma harcaması pozitif dışsalıklara sahip olduğu için çarpan etkisi ile kapasite kullanımını artırarak çıktı düzeyini yükseltecektir. Bu teori pozitif dışsallıklara dayanarak savunma harcamalarındaki artışın etkilerini "arz yanlı" olarak açıklamaktadır (Durgun ve Timur, 2017: 130). Diğer yaklaşım ise savunma harcamaları ile ekonomik büyüme arasındaki ilişkinin negatif yönde olduğunu açıklayan talep yanlı Neoklasik Yaklaşım Teorisi'dir (Erbaykal, 2007: 43). Bu yaklaşım savunma harcamalarındaki bir artışın ekonomik büyümeyi geciktireceğini ileri sürmektedir. Zira artan savunma harcamaları çıktı ve gelir seviyesini artırarak paraya olan talebi artıracaktır. Para talebinin artması da faiz oranlarını yükselterek borçlanmanın maliyetini artıracağından yatııımların azalmasına yol açacaktır (Korkmaz, 2015: 274). Savunma harcamalarııın da diğer kamu harcamaları gibi yatırımlar üzerinde bir dışlama etkisi yaratacağından ekonomik büyümeyi negatif yönde etkileyeceği ileri sürülmektedir (Aksoğan vd., 2013: 665). Bu iki yaklaşımın yanı sıra literatürde, savunma harcamaları ile ekonomik büyüme arasında sanıldığı kadar önemli bir ilişkinin olmadığını ileri süren görüşler de mevcuttur (Vitali, 2018: 175-178).

\section{Ampirik Literatür}

Ülkelerin milli gelirinden önemli bir pay alması nedeniyle literatürde savunma harcamalarının ekonomik büyüme üzerindeki etkisini inceleyen birçok teorik ve ampirik çalışma bulunmaktadır. Söz konusu çalışmaların bir kısmı (Ateşoğlu, 2002; Sümer, 2005; Yurttançıkmaz, Aali ve Emsen; 2012; Yıldırım ve Öcal, 2016; Ismail, 2017) Keynesci Yaklaşımı savunurken diğerleri (Başar ve Künü, 2012; Altay, Ekinci ve Peçe, 2013; Özsağır, 2013; Jabar, Khalid ve Razaq, 2015; Korkmaz, 2015; Topal, 2018) Neoklasik Yaklaşıma işaret etmektedir. Diğer yandan bazı çalışmalar ise (Biswas ve Ram, 1986; Dunne ve Nikolaidou, 2012; Papanikos, 2015; Kollias ve Paleologou 2016;) söz konusu değişkenler arasında önemli bir ilişkinin olmadığı veya bu ilişkinin inmal edilebilir olduğunu vurgulamaktadır. 
Dakurah vd. (2001), Granger nedensellik yöntemini kullanarak 62 gelişmekte olan ülkede 1975-1995 dönemi için savunma harcamaları ile ekonomik büyüme arasındaki nedensellik ilişkisini araştırmışlardır. Elde edilen bulgulara göre, 23 ülkede savunma harcamaları ile ekonomik büyüme arasında tek yönlü nedensellik ilişkisi bulunurken 7 ülkede çift yönlü nedensellik olduğu sonucuna ulaşılmıştır.

Gökbunar ve Yanıkkaya (2004) çalışmalarında 1980-1997 yılları arasında savunma harcamalarının ekonomik büyüme üzerindeki etkisini 100 'ün üzerinde ülke için panel veri analizi ile tahmin etmişlerdir. Çalışmada ele alınan ülkeler için ulaşılan sonuç savunma harcamaları ile ekonomik büyüme arasında anlamlı bir ilişkinin olmadığı yönündedir. Ülkeler gelir gruplarına göre sınıflandırıldığında ise savunma harcamalarının gelişmekte olan ülkelerin büyümelerini pozitif olarak etkilediği sonucuna ulaşılırken, gelişmiş ülkeler için bu ilişkinin anlamlı olmadığı görülmüştür.

Diğer yandan savunma harcamaları ile ekonomik büyüme ilişkisini talep ve arz yönlü yaklaşımlar çerçevesinde açıklayan Giray (2004), 1998-2002 dönemine ait savunma harcamaları verilerini kullanarak karşılaştırma yapmıştır. Çalışmada Türkiye' de savunma harcamalarının NATO ülkeleri ile karşılaştııılığında oldukça yüksek olduğu gözlemlenmiştir. Ampirik analiz sonuçlarına göre savunma harcamaları ile eğitim harcamaları arasında pozitif yönlü, savunma harcamaları ile sağlık harcamaları arasında ise negatif yönlü ilişki olduğu görülmüştür.

Keynesyen Yaklaşımı savunan çalışmalardan biri olan Sümer (2005), askeri harcamaların iktisadi büyüme üzerindeki etkisini Almanya, Amerika, Azerbaycan, Bulgaristan, Çin, Ermenistan, Fransa, Gürcistan, İngiltere, Irak, İran, İsrail, Japonya, Kıbrıs (Kıbrıs Rum Yönetimi), Rusya, Suriye, Türkiye, Ukrayna ve Yunanistan için analiz etmiştir. Söz konusu çalışmada 1990-2001 yıllarını kapsayan GSMH verileri kullanılarak panel veri analizi gerçekleştirilmiştir. Bulgulara göre kendi savunma teçhizatlarını üretebilen nitelikteki ülkelerin savunma sanayi harcamalarının ekonomik büyüme üzerinde pozitif bir etki yarattığı sonucuna ulaşmıştır. Fakat savunma sanayinde dışarıya bağımlı ülkelerde (Almanya hariç) bu etkinin negatif olduğu tespit edilmiştir.

Pieroni (2009), askeri harcamaların ekonomik büyüme üzerindeki etkisini doğrusal olmayan bir model ile ele almıştır. Ampirik analiz aynı zamanda askeri harcamalar ile askeri olmayan harcamaların payı arasındaki etkileşimi dikkate alan bir değişken içermektedir. Yüksek ve düşük askeri harcama yapan 90 ülkenin analize dâhil edildiği çalışmada yüksek düzeyde askeri harcama yapan ülkelerde askeri harcamalar ile ekonomik büyüme arasında negatif yönlü bir ilişki olduğu bulunmuştur.

Neoklasik yaklaşımı destekleyen bulgular elde eden Başar ve Künü (2012), 1997-2004 dönemine ait veriler ile 36 ülke için savunma harcamalarının ekonomik büyümeye etkisini panel veri analizi ve regresyon modeli ile analiz etmişlerdir. Sabit etkili model tahmininden elde ettikleri sonuçlara göre savunma harcamaları arttıkça büyüme oranlarının azaldığını belirlemişlerdir.

Yurttançıkmaz vd. (2012) çalışmalarında askeri harcamaların ve dışa açıklığın ekonomik büyüme üzerindeki etkilerini kısa ve uzun dönem için analiz etmişlerdir. Çalışmada Irak Savaşı́nın neden olduğu kayıpların İran ekonomisinde meydana getirdiği değişiklikler, yaptırımlar, ambargo ve savunma harcamalarının ekonomik büyüme üzerindeki etkileri 1965-2008 dönemi için sermaye birikimi, dış ticaret hacmi, askeri harcamalar, işgücü ve yükseköğrenim eğitim harcamaları değişkenleri kullanılarak sınır testi yöntemi ile araştırılmıştır. Uzun dönemde askeri harcamalar ve dışa açıklığın ekonomik büyümeyi olumlu yönde etkilediği tespit edilmiştir. Diğer yandan kısa dönemde askeri harcamaların ekonomik büyümeyi olumlu etkilemesine karşın dışa açıklığın anlamlı etkiler doğurmadığı sonucuna ulaşmışlardır.

Türkiye üzerine yapılan çalışmalardan bir olan Soyyiğit (2013) 1970-2013 dönemi için savunma harcamaları ile GSYH, istihdam ve ithalat değişkenleri arasındaki nedensellik ilişkisini Granger Nedensellik ve Toda-Yamamoto Yaklaşımı ile incelemiştir. Granger Nedensellik Testi sonuçlarına göre savunma harcamaları ile istihdam arasında çift yönlü nedenselliğe rastlarken, Toda-Yamamoto yaklaşımına göre istihdamdan savunma harcamalarına ve savunma harcamalarından GSMH'ya doğru tek yönlü bir nedensellik olduğu görülmüştür. 1923-2012 dönemine ait verilerini kullanan Özsağır (2013) ise ekonominin darbe dönemlerinde nasıl bir seyir izlediğini incelemiştir. Özsağır (2013) klasik regresyon modelini kullanarak Türkiye örneği 
üzerinden darbelerin etkisini kukla değişken yardımıyla ele almıştır. Çalışmanın ampirik bulgularında darbe ve darbe teşebbüslerinin ekonomiyi olumsuz yönde etkilediği ve ekonominin darbe döneminde $1 / 4$ oranında küçüldüğü sonucuna ulaşılmıştır.

Diğer çalışmalardan farklı olarak Altay vd. (2013), Ortadoğu'da yaşanan terörün Türkiye, Mısır, Suudi Arabistan ekonomileri üzerindeki etkilerini ele almışlardır. 1996-2010 dönemine ait verilerle gerçekleştirilen panel veri analizinde terör olaylarının yaşandığı ülkelerde yatırımcıların yatırımlarını geri çektiği ve bunun sonucunda üretimde gerileme yaşandığı sonucuna ulaşılmıştır. Dolayısıyla üretimde yaşanan gerileme, işsizliğin artması ve yurt dışından mal ve hizmet talebinin gerilemesi anlamını taşımaktadır. Bu kısır döngü ise Neoklasik Yaklaşımın savunduğu gibi GSMH'yı ve KBMH (Kişi Başına Milli Hasıla)'yı olumsuz etkileyecektir.

Neoklasik görüşü destekleyen Jabar vd. (2015) çalışmalarında 1970-2011 döneminde ABD için askeri harcamalar ve ekonomik büyüme arasındaki ilişkiyi ARDL (Autoregressive Distribution Lag) modelini kullanarak ele almışlardır. Çalışmada askeri harcamaların azaltılmasının ekonomik büyümeyi teşvik edeceği sonucuna ulaşılmıştır. Dolayısıyla değişkenler arasındaki ilişki negatif yönlü ve istatistiksel olarak anlamlıdır.

Korkmaz (2015) çalışmasında askeri harcamaların, ekonomik büyüme ve işsizlik değişkenleri üzerindeki etkisini 2005-2012 yıllarına ait verileri kullanarak 10 Akdeniz ülkesi için panel veri analizi ile tahmin etmiştir. Çalışmanın sonucunda askeri harcamalardaki artışın ekonomik büyümeyi olumsuz etkilediği dolayısıyla işsizliğin attığı gözlemlenmiştir. Askeri ve siyasi istikrarı olmayan ülkelerin askeri harcamaya yönelik yatırımları arttırmasının hükümetleri eğitim, sağlık ve altyapı gibi yatırımlara daha az kaynak ayırmaya zorlayarak toplumsal refahın da olumsuz etkilenmesine yol açacağı savunulmuştur. Bu yüzden ülkelerin ekonomik büyümeyi artırmak için askeri harcamalarını azaltmaları gerektiği ileri sürülmüştür.

Diğer yandan Bildirici (2016), 1987-2013 verileri ile Çin için ekonomik büyüme, enerji tüketimi ve savunma harcamaları değişkenleri arasındaki ilişkiyi eşbütünleşme testi ve Granger nedensellik testini kullanarak açıklamaya çalışmıştır. Eşbütünleşme testi sonuçları savunma ve enerji tüketiminin Çin'in ekonomik büyümesi üzerinde olumlu ve istatistiksel olarak anlamlı bir etkisi olduğu yönündedir. Bu sonuçlara paralel olarak Granger nedensellik testi değişkenler arasında pozitif ve anlamlı bir nedensel ilişkiyi işaret etmiştir. Ismail (2017)'de çalışmasında Keynesci Yaklaşımı destekleyen sonuçlar elde etmiştir. 1988-2013 dönemi için beş Güney Asya ülkesini kapsayan çalışmada askeri harcamaların ekonomik büyüme üzerindeki etkisi panel veri analizi ile tahmin edilmiştir. Çalışmada ulaşılan sonuçlar ülkelerarasında olan eşitsizlikleri doğrulamakta ve askeri harcamaların ekonomik büyüme üzerinde olumlu etkisi olduğuna işaret etmektedir. Çalışma Güney Asya Bölgesi(SAR)'nde ekonomik büyüme oranlarını artırabilmek için barış̧ıl bir ortama ihtiyaç olduğunu vurgulamaktadır. Ayrıca daha yüksek askeri harcamalar yoluyla ekonomik büyümenin sağlanmasının etkili ve verimli bir yol olmadığı savunulmuştur.

1960-2015 döneminde Türkiye ve Amerika Birleşik Devletleri için askeri harcamalar ve ekonomik büyüme arasındaki ilişkiyi inceleyen Bilgin ve Korkmaz (2017) Johansen-Juselius eşbütünleşme ve Granger nedensellik analizlerini kullanmıştır. Johansen-Juselius eşbütünleşme analizine göre Türkiye ve ABD için ithalat, GSYH, ihracat ve askeri harcamalar arasında uzun dönemli bir ilişkinin varlı̆̆ı tespit edilmiştir. Granger nedensellik analizine göre ise Türkiye için ekonomik büyüme ve askeri harcamalar arasında çift yönlü bir nedensellik ilişkisi olmasına rağmen, $A B D$ için söz konusu değişkenler arasında herhangi bir nedensellik ilişkisi tespit edilememiştir.

Topal (2018) çalışmasında Türkiye'nin 1960-2016 dönemine ait yıllık verilerini ele alarak askeri harcamalar ile ekonomik büyüme arasındaki ilişkiyi yapısal kırılmalı ve yapısal kırılmasız eşbütünleşme ve nedensellik analizi yöntemleriyle araştırmıştır. Çalışmada askeri harcamalardan ekonomik büyümeye doğru negatif yönlü nedensellik olduğu sonucuna ulaşılmıştır. Ancak dönemin koşullarına göre Türkiye'de askeri harcama ile ekonomik büyüme arasındaki ilişkinin istatistiksel olarak anlamsızlaştığı görülmüştür.

Yine Vitali (2018), italya için savunma harcamaları ile ekonomik büyüme ilişkisini araştırmıştır. Diğer çalışmalardan farklı olarak ekonometrik bir model kurmak yerine var olan araştırmalardan bir tahmin formüle edilerek analiz yapılmıştır. Sonuç olarak askeri harcamaların İtalya'nın ekonomik büyümesi üzerinde önemli bir etkiye sahip olmadığı sonucuna ulaşılımıştır. 
Son döneme ait çalışmalardan biri olan Lobont vd. (2019) çalışmalarında askeri harcamaların büyüme üzerindeki etkisini 1991-2016 dönemine ait yıllık verileri kullanılarak Romanya için analiz etmişlerdir. Granger nedensellik testinin kullanıldığı ampirik analiz sonuçları askeri harcama ile GSYH arasında uzun dönemde iki yönlü bir ilişki olduğuna işaret etmektedir. 3 farklı modelin ele alındığı çalışmada tüm modellerde askeri harcamaların ekonomik büyüme üzerindeki etkisinin pozitif yönde olduğu görülmüştür.

\section{Türkiye Üzerine Uygulama}

\subsection{Yöntem ve Veri Seti}

Çalışmada Türkiye için savunma harcamaları ile ekonomik büyüme arasındaki ilişkiyi sınamak amacıyla 1984-2016 dönemine ilişkin yıllık veriler kullanılmıştır. Söz konusu veri seti Dünya Bankası (WB)'dan derlenmiştir. Ayrıca değişkenlerin aynı düzeye getirilmesi ve paralelliğin sağlanması için logaritmaları alınmıştır. Büyümeyi temsilen gayri safi yurt içi hâsıla (LGSYH), savunma harcamalarını temsilen toplam savunma harcamaları (LSAH) ve teknolojiyi temsilen kişi başına patent sayısı (LPAT) kullanılmıştır. Gayrisafi Yurtiçi Hâsıla (GSYH)'nın logaritması alınarak büyüme oranı elde edilmiştir. Savunma harcamalarının reelleştirilmesi için cari değerler deflatöre oranlanmıştır. Değişkenler arasındaki ilişki ARDL (Otoregresif Dağıtılmış Gecikme Modeli) Sınır Testi ve Johansen Eşbütünleşme Testi ile araştırılmaktadır. Ayrıca değişkenler arasındaki kısa ve uzun dönem ilişkilerin yönünün belirlenmesi amacıyla Granger Nedensellik testine başvurulmuştur.

Tablo 3. Değişkenlere Illişkin Açıklamalar ve Veri Kaynakları

\begin{tabular}{|l|c|c|}
\hline Değişken & Açıklama & Kaynak \\
\hline GSYH & GSYH'nin logaritması & Dünya Bankası(World Bank) \\
\hline Savunma Harcamaları & Savunma Harcamalarının logaritması & Dünya Bankası(World Bank) \\
\hline Patent Sayısı & $\begin{array}{c}\text { Kişi başına Patent sayısının } \\
\text { logaritması }\end{array}$ & Dünya Bankası(World Bank) \\
\hline
\end{tabular}

\subsection{Birim Kök Testleri}

Bir zaman serisinin ortalaması ile varyansı zaman içinde sabitse ve iki dönem arasındaki kovaryansı bu kovaryansın hesaplandığı asıl döneme değil de yalnızca iki dönem arasındaki uzaklığa bağlıysa bu zaman serisi durağandır (Gujarati, 2016: 319). Ele alınan modelde sahte regresyon ya da anlamsız regresyon sorununun olmaması için kullanılacak serinin durağan olması (birim kök içermemesi) gerekmektedir (Nargeleçekenler ve Sevüktekin, 2010: 305). Zira durağan olmayan bir zaman serisinin bir ya da daha fazla durağan olmayan zaman serilerine göre regresyonunda sahte regresyona bağlı olarak yüksek $R^{2}$ değeri bulunabilir ve regresyon katsayılarının bazıları ya da tamamı istatistiksel olarak anlamlı çıkabilir (Gujarati, 2016: 320). Çalışmada bu amaçla kullanılan ADF (Augmented Dickey-Fuller) ve PP (Philips Perron) birim kök testleri yardımı ile serilerin durağanlıkları sınanmaktadır. Serilerin durağan olmaması halinde farkları alınarak durağan hale getirilmektedir. Tablo 4'e göre çalışmada kullanılan değişkenlerin hiçbirinin düzeyde durağan olmadığı görülmektedir.

Tablo 4. Değişkenlerin Düzey Değerlerinin Durağanlık Testi

\begin{tabular}{|l|c|c|c|c|c|c|}
\hline & \multicolumn{3}{|c|}{ ADF } & \multicolumn{3}{c|}{ PP } \\
\hline Değişkenler & t-istatistik & \%5 önem düzeyi & p-değeri & t-istatistik & \%5 önem düzeyi & p-değeri \\
& & & & & & \\
\hline LGSYH & $-2,299385$ & $-3,557759$ & 0,4223 & $-2,299385$ & $-3,557759$ & 0,4223 \\
\hline LSAH & 1,908829 & $-1,951332$ & 0,9845 & 2,144501 & $-1,951332$ & 0,9908 \\
\hline LPAT & 2,038842 & $-3,557759$ & 0,5587 & $-2,010335$ & $-3,557759$ & 0,5738 \\
\hline
\end{tabular}


Düzeyde durağan olmayan değişkenlerin farkları alınarak birim kök testleri uygulandığında birinci farklarında durağan duruma geldikleri görülmektedir. Tablo 5 'te değişkenlerin birinci farklarının ADF ve PP birim kök testleri ile durağanlığı test edilmiştir. t-istatistik değerleri \%5 önem düzeyinden mutlak olarak büyük olduğundan değişkenlerin tümü I(1)'de durağandır. Bu durumda değişkenler arasındaki eşbütünleşmeden bahsedilebilmektedir (Tarı, 2010: 415-416).

Tablo 5. Değişkenlerin Birinci Farklarının Durağanlık Testi

\begin{tabular}{|l|c|c|c|c|c|c|}
\hline & \multicolumn{3}{|c|}{ ADF } & \multicolumn{3}{c|}{ PP } \\
\hline Değişkenler & t-istatistiği & $\begin{array}{c}\text { \%5 önem } \\
\text { düzeyi }\end{array}$ & p-değeri & t-istatistiği & $\begin{array}{c}\text { \%5 önem } \\
\text { düzeyi }\end{array}$ & p-değeri \\
\hline D(LGSYH) & $-5,842004$ & $-2,960411$ & $0,0000^{*}$ & $-5,842004$ & $-2,960411$ & $0,0000^{*}$ \\
\hline D(LSAH) & $-5,339835$ & $-1,951687$ & $0,0000^{*}$ & $-5,948717$ & $-3,562882$ & $0,0002^{*}$ \\
\hline D(LPAT) & $-5,904947$ & $-3,562882$ & $0,0002^{*}$ & $-5,347082$ & $-1,951687$ & $0,0000^{*}$ \\
\hline
\end{tabular}

* \%1,\%5 ve \%10 önem düzeyinde değişkenler durağandır.

\subsection{Johansen-Eşbütünleşme Testi}

Johansen eşbütünleşme testi (1988) birden fazla eşbütünleşme ilişkisini analiz etmek için kullanılmaktadır ve Engle-Granger (1987) iki aşamalı eşbütünleşme testinin eksikliklerini aşmak için geliştirilmiştir. Eşbütünleşme sınama istatistikleri aşağıdaki gibi formülleştirilmektedir:

$$
\begin{aligned}
& \lambda_{\mathrm{iz}}(\mathrm{r})=-\mathrm{T} \sum_{i=r+1}^{n} \ln \left(1-\hat{\lambda}_{\mathrm{i}}\right) \\
& \lambda_{\text {max }}(\mathrm{r}, \mathrm{r}+1)=-\mathrm{T} \ln \left(1-\hat{\lambda}_{\mathrm{r}+1}\right)
\end{aligned}
$$

$\lambda_{\text {iz }}$ eşbütünleşik vektör sayısı küçük eşit $r$ boş hipotezini belirsiz alternatifine karşı sınar $\left(\mathrm{H}_{0}: p \leq r \quad H_{1}\right.$ : $p$ belirsiz). $\lambda_{\max }$ eşbütünleşik vektör sayısı eşittir $r$ boş hipotezini $r+1$ alternatifine karşı sınamaktadır ( $H_{0}: p=r$ $\left.\mathrm{H}_{1}: p=r+1\right)$.

Tablo 6. Gecikme Uzunluğunun Belirlenmesi

\begin{tabular}{|c|c|c|c|c|c|}
\hline Gecikme Uzunluğu & LR & FPE & AIC & SC & HQ \\
\hline $\mathbf{0}$ & NA & 0,000161 & $-0,218661$ & $-0,077217$ & $-0,174362$ \\
\hline $\mathbf{1}$ & 168,4186 & $3,58 \mathrm{e}-07$ & $-6,334716$ & $-5,768939^{*}$ & $-6,157522$ \\
\hline $\mathbf{2}$ & 9,794336 & $4,37 \mathrm{e}-07$ & $-6,159224$ & $-5,169113$ & $-5,849133$ \\
\hline $\mathbf{3}$ & 14,08944 & $4,11 \mathrm{e}-07$ & $-6,280083$ & $-4,865639$ & $-5,837097$ \\
\hline $\mathbf{4}$ & $\mathbf{2 1 , 6 1 7 0 1 ^ { * }}$ & $\mathbf{2 , 2 2 \mathrm { e } - 0 7 ^ { * }}$ & $-7,010457^{*}$ & $-5,171680$ & $-6,434575^{*}$ \\
\hline
\end{tabular}

Eşbütünleşme testi öncesi gecikme uzunluğunun belirlenmesi gerekmektedir. Tablo 6 'da yer alan kriterlerin çoğunluğu (LR, FPE, AIC, SC, HQ) uygun gecikme uzunluğu olarak 4 gecikmeyi işaret etmektedir. Dolayısıyla bu gecikme uzunluklarında kurulan modelde yapısal bir sorun olmayacaktır.

Tablo 7. Johansen Eşbütünleşme Testi Sonuçları

\begin{tabular}{|l|c|c|c|c|c|c|}
\hline \multicolumn{7}{|c|}{ Değişkenler: LGSYH LSAH LPAT } \\
\hline Hipotezler & İz İstatistiği & Kritik Değer & P-değer & Max-Özdeğer & Kritik Değer & P-değer \\
\hline Yok* & 44,02846 & 29,79707 & 0,0006 & 27,28028 & 21,13162 & 0,0060 \\
\hline En Fazla 1* & 16,74818 & 15,49471 & 0,0322 & 16,74230 & 14,26460 & 0,0199 \\
\hline En Fazla 2 & 0,005882 & 3,841466 & 0,9381 & 0,005882 & 3,841466 & 0,9381 \\
\hline
\end{tabular}


Johansen Eşbütünleşme testinde eşbütünleşik denklem sayısı ile sınama yapılmaktadır. İz istatistiği ve max-özdeğer için hesaplanan değerler kritik değerlerden büyük olduğunda \%5 anlamlılık düzeyinde Ho hipotezi reddedilmektedir. Tablo 7'ye göre "hiç eşbütünleşik vektör yoktur" şeklindeki 1. Hipotez ve "En çok 1 eşbütünleşik vektör bulunmaktadır" biçimindeki 2. Hipotez reddedilmiştir. "En çok 2 eşbütünleşik vektör bulunmaktadır" şeklindeki 3. hipotez ise reddedilememiştir. Diğer bir ifadeyle sonuçlar değişkenler arasında iki eşbütünleşik vektör olduğunu göstermektedir. Yani LGSYH, LPAT ve LSAH değişkenleri arasında uzun dönemli 2 vektörel ilişki bulunmaktadır.

\subsection{ARDL Modeli}

Diğer eşbütünleşme metotlarıyla karşılaştırıldığında birçok ekonometrik avantajlara sahip olan ve Pesaran vd. (2001) tarafından geliştirilen ARDL (Autoregressive distributed lag) yaklaşımı serilerin I(0), I(1) veya parçalı bütünleşik olup olmadığına bakmaksızın aralarındaki eşbütünleşme ilişkisinin varlığını araştırılabilmektedir. Bu yaklaşımın diğer bir avantajı ise, küçük örneklemlerde sağlam ve etkin sonuçlar vermesidir. Ayrıca, dinamik hata düzeltme modeli (ECM), ARDL'den elde edilebilmektedir (Pazarlıoğlu ve Gülay, 2007: 9).

Çalışmada ele alınan değişkenlerin tümü farkta durağan olduğundan savunma harcamaları, teknolojik değişim ve ekonomik büyüme arasındaki uzun dönemli ilişkinin varlığı ARDL yaklaşımı çerçevesinde de ele alınabilmektedir. Zira ARDL sınır testi için serilerin I(0) ve I(1) veya bütün değişkenlerin I(1) olmaları gerekmektedir. Çalışmada kullanılacak olan ARDL modelinin denklemi aşağıdaki biçimdedir:

$$
\mathrm{LGSYH}=\beta_{0}+\sum_{\mathrm{i}=1}^{\mathrm{p}} \beta_{1} \mathrm{LGSYH}_{\mathrm{t}-\mathrm{p}}+\sum_{\mathrm{i}=0}^{\mathrm{p}} \beta_{2} \mathrm{LPAT}_{\mathrm{t}-\mathrm{p}}+\sum_{\mathrm{i}=0}^{\mathrm{p}} \beta_{3} \mathrm{LSAH}_{\mathrm{t}-\mathrm{p}}+\varepsilon_{\mathrm{t}}
$$

ARDL modelinde öncelikle optimal gecikme uzunluğu belirlenmektedir. Bu doğrultuda Akaike Bilgi Kriteri (AIC)'ne göre Şekil 3'te de görüldüğü üzere gecikme uzunlukları $(4,4,4)$ olarak tespit edilmiştir.

Şekil 3. Gecikme Uzunluğu

Akaike Information Criteria (top 20 models)

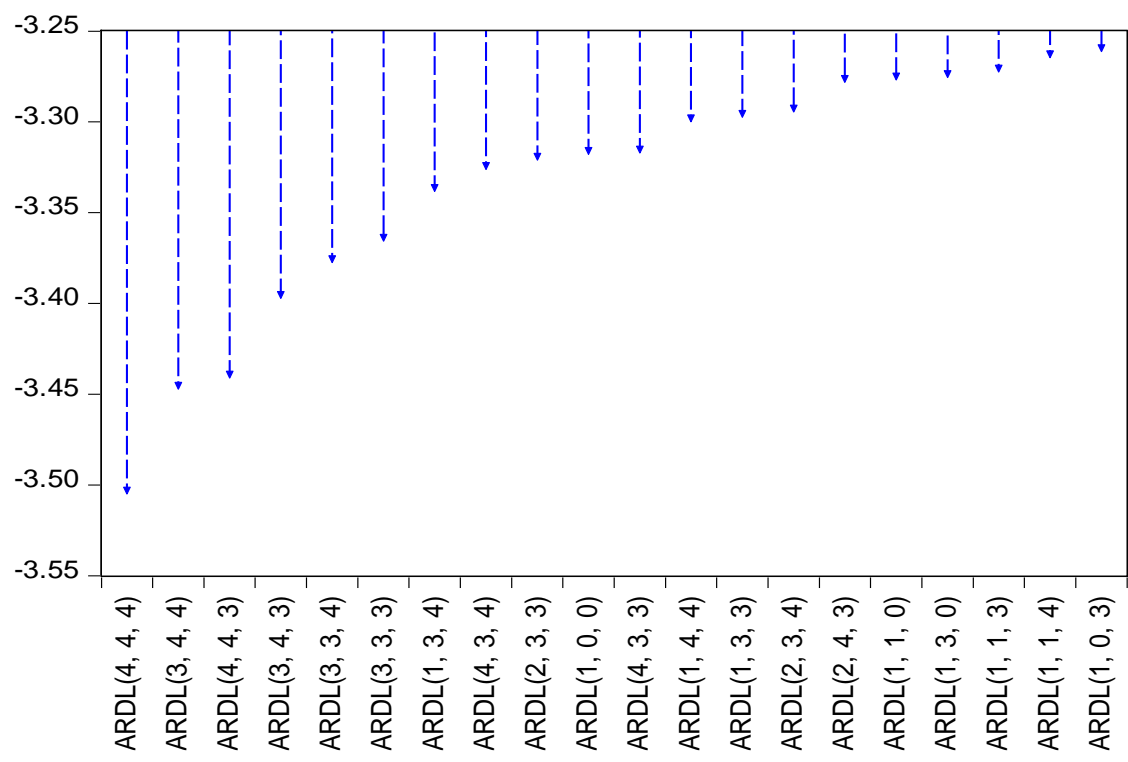


$\operatorname{ARDL}(4,4,4)$ modelinin tahmin sonuçları Tablo 8'de yer almaktadır. Tabloya göre uzun dönemde savunma harcamaları GSYH'yi pozitif yönde etkilemektedir, ancak savunma harcamalarının cari değeri istatistiksel olarak anlamlı değildir. Diğer yandan Johansen Eşbütünleşme testi sonuçlarının aksine ARDL modelinden elde edilen bulgulara göre teknolojik gelişme ile ekonomik büyüme arasında istatistiki açıdan anlamlı ve pozitif yönlü bir ilişki olduğu görülmektedir.

Tablo 8. ARDL $(4,4,4)$ Modeli Tahmini Sonuçları (Bağımlı Değişken: GSYH)

\begin{tabular}{|l|c|c|c|c|}
\hline Değişkenler & Katsayı & Standart Hata & t-istatistik & P-Değeri \\
\hline LGSYH(-1) & 0,466743 & 0,231768 & 2,013841 & 0,0637 \\
\hline LGSYH(-2) & 0,159697 & 0,266508 & 0,599220 & 0,5586 \\
\hline LGSYH(-3) & $-0,325994$ & 0,220705 & $-1,477060$ & 0,1618 \\
\hline LGSYH(-4) & $-0,326316$ & 0,237289 & $-1,375182$ & 0,1907 \\
\hline LPAT & 0,162221 & 0,074176 & 2,186971 & 0,0462 \\
\hline LPAT (-1) & 0,067735 & 0,095752 & 0,707402 & 0,4909 \\
\hline LPAT(-2) & $-0,173173$ & 0,078541 & $-2,204881$ & 0,0447 \\
\hline LPAT (-3) & 0,093653 & 0,079311 & 1,180840 & 0,2573 \\
\hline LPAT (-4) & 0,097542 & 0,069136 & 1,410866 & 0,1801 \\
\hline LSAH & 0,156323 & 0,137561 & 1,136396 & 0,2749 \\
\hline LSAH(-1) & 0,270302 & 0,126814 & 2,131479 & 0,0513 \\
\hline LSAH(-2) & $-0,083892$ & 0,138125 & $-0,607363$ & 0,5533 \\
\hline LSAH(-3) & 0,071421 & 0,141732 & 0,503913 & 0,6222 \\
\hline LSAH(-4) & 0,255406 & 0,128698 & 1,984546 & 0,0672 \\
\hline C & 17,84653 & 4,950339 & 3,605113 & 0,0029 \\
\hline$R^{2}=0,995217$ & DW=2,223717 & & & \\
\hline
\end{tabular}

Modelin istikrarlı olup olmadığını test etmek için CUSUM ve CUSUMSQ yapısal kırılma testleri yapılmış ve uzun dönem katsayılarının istikrarlı olduğu (yapısal kırılma olmadığı) sonucuna ulaşılmıştır.

Şekil 4. CUSUM ve CUSUMSQ Test Grafiği

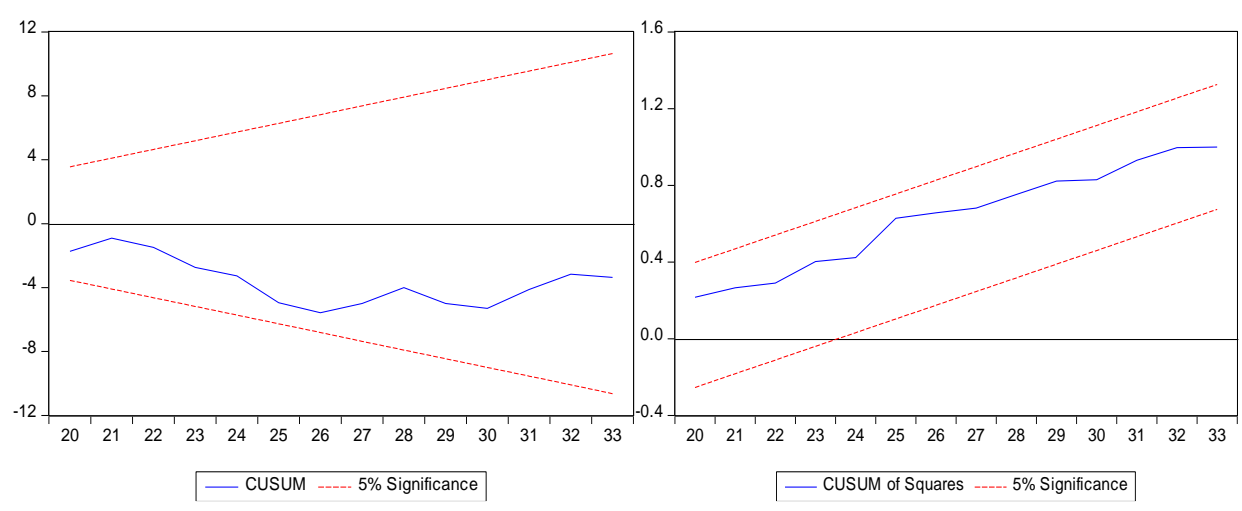

Modelde oto-korelasyon ve değişen varyans sorunlarının varlığı test edilmiştir ve sonuçlar Tablo 9'da yer almaktadır. Analizlere göre modelde otokorelasyon ve değişen varyans problemlerinin olmadığı görülmektedir. Diğer yandan Jarque-Bera testi ile normallik test edilmiş ve Jarque Bera'nın p değeri 0,416767 olarak bulunmuştur. Bu sonuca göre değişkenler normal dağılmaktadır, dolayısıyla ARDL $(4,4,4)$ uzun dönem test sonuçları modelin sapmasız ve tutarlı olduğunu göstermektedir. 
Tablo 9. Tanı Testleri

\begin{tabular}{|l|c|c|}
\hline \multicolumn{1}{|c|}{ TEST } & F-Değeri & P-Değeri \\
\hline Breusch- Godfrey LM Testi (Korelasyon) & 0,662996 & 0,6318 \\
\hline Breusch -Pagan-Godfrey (Değişen Varyans) & 1,711236 & 0,1632 \\
\hline
\end{tabular}

ARDL sınır testi sonuçları ise Tablo 10 'da gösterildiği gibidir. Elde edilen istatistik değerlerinin sınırlar arasında yer alması durumunda testin yetersiz olduğu sonucuna ulaşılmaktadır. Üst sınırın üzerindeyse $\mathrm{H}_{0}$ hipotezi reddedilmekte, alt sınırın altında ise $\mathrm{H}_{0}$ hipotezi reddedilememektedir. Değişkenlerin F-istatistik değeri üst sınırdan büyük olduğundan boş hipotez reddedilerek eşbütünleşme ilişkisinin olduğu sonucuna ulaşıımaktadır. Dolayısıyla değişkenler arasında uzun dönem ilişkisi kurulabilmektedir.

Tablo 10. ARDL Sınır Testi

\begin{tabular}{|l|c|c|c|}
\hline F-statistik & Önem düzeyi & Alt sını & Üst sını \\
\hline $\mathbf{5 . 8 1 4 3 5 9}$ & $\% 10$ & 2,63 & 3,35 \\
\hline & $\% 5$ & 3,1 & 3,87 \\
\hline & $\% 2,5$ & 3,55 & 4,38 \\
\hline & $\% 1$ & 4,13 & 5 \\
\hline
\end{tabular}

ARDL sınır testi uzun dönem katsayıları Tablo 11'de yer almaktadır. Sonuçlara göre uzun dönem katsayılarında LPAT ve LSAH istatistiksel olarak anlamlıdır ve her iki değişkende uzun dönemde ekonomik büyümeyi olumlu yönde etkilemektedir. Patent sayısında meydana gelen $\% 1^{\prime}$ lik bir artış uzun dönemde ekonomik büyümede \%0,241'lik bir artış meydana getirmektedir. Savunma harcamalarında meydana gelen $\% 1^{\prime}$ lik bir artış ise ekonomik büyümede \%0,652'lik bir artış ile sonuçlanacaktır. Bu sonuç ele alınan dönemde Türkiye ekonomisi için savunma harcamalarının ekonomik büyüme üzerindeki olumlu etkisinin teknolojik gelişmeden daha fazla olduğu biçiminde yorumlanabilir.

Tablo 11. ARDL Sınır Testi Uzun Dönem Katsayıları

\begin{tabular}{|l|c|c|c|c|}
\hline Değişkenler & Katsayı & Standart Hata & t-istatistik & P-Değeri \\
\hline LPAT & 0,241726 & 0,010795 & 22,39277 & 0,0000 \\
\hline LSAH & 0,652676 & 0,049459 & 13,19631 & 0,0000 \\
\hline C & 17,39648 & 1,014903 & 17,14103 & 0,0000 \\
\hline
\end{tabular}

\subsection{Vektör Hata Düzeltme Modeli}

Değişkenler arasındaki kısa dönem ilişkisini araştıran hata düzeltme modeli aşağıdaki biçimdedir:

$$
\Delta \mathrm{LGSYH}=\sum_{\mathrm{i}=1}^{\mathrm{p}} \beta_{1} \Delta \mathrm{LGSYH}_{\mathrm{t}-\mathrm{p}}+\sum_{\mathrm{i}=0}^{\mathrm{p}} \beta_{2} \Delta \mathrm{LPAT}_{\mathrm{t}-\mathrm{p}}+\sum_{\mathrm{i}=0}^{\mathrm{p}} \beta_{3} \Delta \mathrm{LSAH}_{\mathrm{t}-\mathrm{p}}+\Delta \mathrm{ECT}_{\mathrm{t}-1}+\varepsilon_{\mathrm{t}}
$$

Tablo 12' de değişkenler arasında kısa dönem ilişkiyi inceleyen ARDL hata düzeltme modeli sonuçları yer almaktadır. Tabloya göre patent sayısı ve savunma harcamaları ekonomik büyümeyi kısa dönemde de pozitif yönde etkilemektedir. Patent sayısında meydana gelen \%1'lik bir artış cari dönemde ekonomik büyümeyi \%0,162 oranında artırırken, savunma harcamalarındaki \%1'lik bir artış ise ekonomik büyümede $\% 0,156$ 'ık bir yükselişe yol açacaktır. Diğer bir ifadeyle uzun dönemin aksine kısa dönemde teknolojik değişim ve savunma harcamalarının ekonomik büyüme üzerindeki olumlu etkisi birbirine yakındır. Bağımlı ve bağımsız değişkenler arasında uzun dönemde nedensellikten bahsedebilmek için hata düzeltme modeli katsayısının negatif ve anlamlı olması gerekmektedir. Hata düzeltme tahmin sonuçlarına göre hata düzeltme terimi 
katsayısının değeri -1,025'tir ve istatistiksel olarak anlamlıdır. Bu da kısa dönemde meydana gelen dengeden sapmaların uzun dönemde dengeye yaklaştığını ifade etmektedir. Kısa dönemde ortaya çıkacak dengesizlik bir dönem sonra yaklaşık \%102 oranında düzelecektir.

Tablo 12: Kısa Dönem Hata Düzeltme Modeli Sonuçları

\begin{tabular}{|l|c|c|c|c|}
\hline Değişkenler & Katsayı & Standart Hata & t-ístatistik & P-Değeri \\
\hline D(LGSYH(-1)) & 0,492613 & 0,158936 & 3,099444 & $0,0078^{*}$ \\
\hline D(LGSYH(-2)) & 0,652310 & 0,168830 & 3,863717 & $0,0017^{*}$ \\
\hline D(LGSYH(-3)) & 0,326316 & 0,145087 & 2,249105 & $0,0411^{* *}$ \\
\hline D(LPAT) & 0,162221 & 0,058356 & 2,779826 & $0,0148^{* *}$ \\
\hline D(LPAT(-1)) & $-0,018023$ & 0,051436 & $-0,350397$ & 0,7313 \\
\hline D(LPAT(-2)) & $-0,191195$ & 0,050215 & $-3,807564$ & $0,0019^{*}$ \\
\hline D(LPAT(-3)) & $-0,097542$ & 0,055913 & $-1,744544$ & 0,1030 \\
\hline D(LSAH) & 0,156323 & 0,080773 & 1,935345 & $0,0734^{* * *}$ \\
\hline D(LSAH(-1)) & $-0,242935$ & 0,117495 & $-2,067618$ & $0,0577^{* * *}$ \\
\hline D(LSAH(-2)) & $-0,326827$ & 0,094094 & $-3,473406$ & $0,0037^{*}$ \\
\hline D(LSAH(-3)) & $-0,255406$ & 0,109731 & $-2,327567$ & $0,0354^{* *}$ \\
\hline ECT(-1)* & $-1,025870$ & 0,193042 & $-5,314243$ & $0,0001^{*}$ \\
\hline
\end{tabular}

*\%1 önem düzeyinde , ${ }^{* * \% 5}$ önem düzeyinde ve $* * * \% 10$ önem düzeyinde anlamlıdır.

\subsection{Granger Nedensellik Testi}

Çalışmanın bu aşamasında aralarındaki uzun ve kısa dönem ilişkileri ARDL yöntemi ile tahmin edilen değişkenler arasındaki ilişkinin yönünü tespit etmek amacıyla Granger Nedensellik testi yapılmaktadır.

Granger nedensellik testi aşağıdaki regresyon çiftinin tahminini içermektedir:

$$
\begin{aligned}
& X_{t}=\sum_{i=1}^{m} \alpha_{i} X_{t-i}+\sum_{j=1}^{m} \beta_{j} Y_{t-j}+\lambda_{1} \mathrm{t}+\mathrm{u}_{1 t} \\
& Y_{t}=\sum_{i=1}^{m} \gamma_{i} Y_{t-i}+\sum_{j=1}^{m} \delta_{j} X_{t-j}+\lambda_{2} \mathrm{t}+\mathrm{u}_{2 t}
\end{aligned}
$$

Denklemlerde t zaman ya da trend değişkenidir. Ayrıca $u_{1 t}$ ve $u_{2 t}$ hata terimleri arasında korelasyon olmadığı varsayılmaktadır. Her eşitlik, sistemdeki iki değişkene de ait gecikmeleri kapsamaktadır (Gujarati, 2015: 394).

Tablo 13. Granger Nedensellik Testi Sonuçları

\begin{tabular}{|c|c|c|c|}
\hline & & Ki-Kare İstatistiği & P-Değeri \\
\hline \multirow{2}{*}{ D(LGSYH) } & D(LSAH) & 6,803130 & $0,0784^{*}$ \\
\cline { 2 - 4 } & D(LPAT) & 7,406042 & $0,0600^{*}$ \\
\hline \multirow{2}{*}{ D(LSAH) } & D(LGSYH) & 9,135266 & $0,0275^{*}$ \\
\cline { 2 - 4 } & D(LPAT) & 1,273721 & 0,7354 \\
\hline \multirow{2}{*}{ D(LPAT) } & D(LGSYH) & 2,514044 & 0,4728 \\
\cline { 2 - 4 } & D(LSAH) & 1,663417 & 0,6451 \\
\hline
\end{tabular}

Not: * \%10 anlamlılık düzeyinde istatistiksel anlamlıı̆̆ı ifade etmektedir.

Granger nedensellik testine ilişkin sonuçlara Tablo 13'te yer verilmiştir. Tablo 13'e göre savunma harcamaları ile ekonomik büyüme arasında çift yönlü bir nedensellik ilişkisi vardır. Diğer yandan teknolojiyi temsilen kullanılan kişi başına patent sayısından ekonomik büyümeye doğru tek yönlü bir nedenselliğe 
rastlanmaktadır. Savunma harcamaları ile kişi başına patent sayısı arasında ise herhangi bir nedensellik ilişkisinin var olmadığı sonucuna ulaşılmıştır.

\section{Sonuç}

Bir ülkenin varlığını devam ettirebilmesi için yapması gereken en önemli eylem milli güvenliğini sağlayıp özgür bir ekonomiye sahip olmaktır. Bunun için ülkeler kendi bütçelerinin bir bölümünü savunma harcamalarına ayırmaktadır. Savunma harcamaları ülkelerin güvenliğini sağlaması adına taşıdığı önem ve ülke ekonomisi üzerindeki etkileri itibariyle birçok çalışmaya konu olmuştur.

Türkiye ekonomisi için son dönemde tartışılan iktisadi sorunlardan birisi ülke güvenliğinin sağlanması ve bunun sürdürülebilirliğini devam ettirebilmesidir. Bu doğrultuda teknolojik değişimin de önemi vurgulanmakta ve özellikle savunma sanayiinde teknolojik değişimi teşvik edici yönde politikalar izlenmektedir. Çalışmada Türkiye'de savunma harcamalarının ekonomik büyüme üzerindeki etkisi teknolojik gelişme değişkeni de dikkate alınmak suretiyle analiz edilmiştir. Bu amaç doğrultusunda savunma harcamaları, kişi başına patent sayısı ve ekonomik büyüme değişkenlerine ait 1984-2016 dönemine ilişkin yıllık verileri kullanılmıştır. Ampirik analizde öncelikle değişkenlere ait verilerin durağanlığı ADF ve PP birim kök testleri ile sınanmıştır ve tüm değişkenlerin I(1)'de durağan olduğu sonucuna ulaşılmıştır. Bu sonuçlar doğrultusunda ARDL sınır testi, Johansen eşbütünleşme analizi ve Hata Düzeltme Modeli (VECM) kullanılarak değişkenler arasındaki uzun ve kısa dönem ilişkisi araştııımıştır. Ayrıca değişkenler arasındaki kısa ve uzun dönem ilişkilerinin yönünün belirlenmesi amacıyla Granger nedensellik testine başvurulmuştur.

Johansen eşbütünleşme testi sonuçları değişkenler arasında uzun dönemli bir ilişkinin varlığını doğrulamaktadır. ARDL modelinde elde edilen sonuçlara göre savunma harcamaları ve teknolojiyi temsilen kullanılan patent sayısı değişkenleri ekonomik büyümeyi pozitif yönde etkilemektedir. Dolayısıyla ARDL modelinde elde edilen sonuçlar Keynesyen yaklaşımı desteklemektedir. Uzun dönem katsayıları incelendiğinde patent sayısı ve savunma harcamaları değişkenlerinin her ikisinin de istatistiksel olarak anlamlı olduğu görülmektedir. Savunma harcamaları uzun dönemde büyümeyi pozitif yönde etkilemektedir. Elde edilen sonuç Ateşoğlu (2002), Sümer (2005), Yurttançıkmaz vd. (2012), Yıldııım ve Öcal (2016), Ismail (2017) ve Lobont vd. (2019) çalışmalarını destekler niteliktedir. Ayrıca savunma harcamaları ile ekonomik büyüme arasındaki nedensel ilişkinin çift yönlü olduğu tespit edilmiştir.

Teknolojiyi temsilen modele dâhil edilen patent sayısının ekonomik büyüme üzerindeki etkisinin de pozitif yönlü olduğu görülmektedir. Çalışmadan elde edilen diğer önemli bir sonuç uzun dönem katsayısının daha büyük olması nedeniyle, savunma harcamalarının ekonomik büyüme üzerindeki olumlu etkisinin teknolojik değişimden daha fazla olmasıdır. Elde edilen bu sonucun teknolojik ilerleme konusunda önemli adımların atılmasına karşın gelişmiş ülkelere kıyasla Türkiye'nin bu konuda geride kalmasından kaynaklandığı söylenebilir. Ayrıca çalışmada teknolojik değişimin ekonomik büyüme üzerindeki pozitif etkisinin savunma harcamalarının aksine tek yönlü olduğu görülmüştür. Diğer yanda beklenilenin aksine savunma harcamaları ile teknolojik değişim arasında herhangi bir nedensel ilişkiye rastlanılmamıştır.

ARDL modelinde kısa dönem etkileri Hata Düzeltme modeli ile analiz edilmiştir. Savunma harcamaları ve teknolojik değişimi temsilen modele dâhil edilen patent sayısı ekonomik büyümeyi cari dönemde pozitif yönde etkilemektedir. Ayrıca analiz sonuçları savunma harcamalarındaki bir artışın kısa dönemde ekonomik büyüme üzerinde yarattığı etkinin teknolojik değişimdeki bir artışın etkisi ile yaklaşık olarak aynı boyutta olduğunu göstermektedir. Dolayısıyla ülkemizde savunma harcamalarındaki artışın büyüme açısından önemli bir etken olduğu ifade edilebilir. Ayrıca hata düzeltme modelinin katsayısı negatif ve istatistiksel olarak anlamlı olduğundan kısa dönemde meydana gelen dengeden sapmalar hızla uzun dönemde dengeye yaklaşacaktır.

Ekonomik açıdan bakıldığında, elde edilen sonuçlar gelişmekte olan bir ülke olarak Türkiye'de askeri harcamaların ekonomik büyüme üzerindeki olumlu etkisini vurgulayıcı niteliktedir. Zira konumumuz itibariyle ve uluslararası ticaret yönüyle ulusal savunma sanayine yatırım yapma hem ulusal güvenliğimiz hem de ticaret dengesi açısından fayda sağlayacaktır. Ancak savunma harcamalarındaki artışın sağlık ve eğitim gibi diğer sosyal harcamalar üzerinde oluşturabileceği baskı göz ardı edilmemelidir. 


\section{Beyan ve Açıklamalar (Disclosure Statements)}

1. Bu çalışmanın yazarları, araştırma ve yayın etiği ilkelerine uyduklarını kabul etmektedirler (The authors of this article are admitted that they complied with the principles of research and publication ethics).

2. Yazarlar tarafından herhangi bir çıkar çatışması beyan edilmemiştir (No potential conflict of interest was reported by the authors).

3. Bu çalışma, intihal tarama programı kullanılarak intihal taramasından geçirilmiştir (This article was screened for potential plagiarism using the plagiarism screening program).

\section{Kaynaklar}

Aksoğan, G., Taş, S., \& Örnek, I. (2013). Türkiye'de savunma harcamaları, büyüme ve gelir eşitsizliği, 1970-2008: Ekonometrik bir inceleme. Gaziantep Üniversitesi Sosyal Bilimler Dergisi, 12(3), 659-382.

Altay , H., Ekinci, A., \& Peçe, M. A. (2013). Ortadoğu'da terörün ekonomik etkileri: Türkiye, Mısır ve Suudi Arabistan üzerine bir inceleme. Dumlupınar Üniversitesi Sosyal Bilimler Dergisi, 37, 267-288.

Ateşoğlu, H. S. (2002). Defense spending promotes aggregate output in the United States- Evidence from cointegration analysis. Defence and Peace Economics, 13(1), 55-60.

Başar, S., \& Künü, S. (2012). Savunma harcamalarının iktisadi büyümeye etkisi. Sosyal Bilimler Enstitüsü Dergisi, 10, 130.

Benoit, E. (1978). Growth and defense in developing countries. Economic Development and Cultural Change, 26(2), 271280.

Bildirici, M. (2016). Defense, economic growth and energy consumption in China. Procedia Economics and Finance, 38, 257-263.

Bilgin, T., \& Korkmaz, Ö. (2017). Askeri harcamalar ile ekonomik büyüme arasındaki ilişki: Türkiye ve Amerika Birleşik Devletleri'nin karşılaştırmalı analizi. Uluslararası iktisadi ve Idari Incelemeler Dergisi (IJEAS), 18, 289-316.

Biswas, B., \& Ram, R. (1986). Military spending and economic growth in less developed countries: An augmented model and further evidence. Economic Development and Cultural Change, 34(2), 361-372.

Dakurah, H., Davies, S. P., \& Sampath, R. K. (2001). Defense spending and economic growth in developing countries: A causality analysis. Journal of Policy Modeling, 23, 651-658.

Demir, Ö., \& Tanyıldızı, İ. (2017). Sağlık harcamalarının ekonomik büyüme üzerine etkisi. Fırat Üniversitesi iïBF Uluslararası iktisadi ve Idari Bilimler Dergisi, 1(1), 89-119.

Dickey, D.A., \& Fuller, W.A. (1979). Distribution of the estimators for autoregressive time series with a unit root. Journal of the American Statistical Association, 74 (366), 427-431.

Dunne, J. P., \& Nikolaidou, E. (2012). Defence spending and economic growth in the EU15. Defence and Peace Economics, 23(6), 537-548.

Dunne, J. P., \& Tian, N. (2013). Military spending and growth: A survey. The Economics of Peace and Security Journal, $8(1), 5-11$.

Durgun, Ö., \& Timur, M. C. (2017). Savunma harcamaları ve ekonomik büyüme ilişkisi. Türkiye analizi. Dumlupınar Üniversitesi Sosyal Bilimler Dergisi, (54), 126-137.

Engle, R., \& Granger, C. (1987), Cointegration and error correction representation: Estimation and testing. Econometrica, $55,251-76$.

Erbaykal, E. (2007). Türkiye'de savunma harcamaları ve ekonomik büyüme ilişkisi. Balıkesir Üniversitesi Sosyal Bilimler Enstitüsü, Yüksek Lisans Tezi, Balıkesir.

Giray, F. (2004). Savunma harcamaları ve ekonomik büyüme. Cumhuriyet Üniversitesi iktisadi ve Idari Bilimler Dergisi, 5(1), 181-196.

Gökbunar, R., \& Yanıkkaya, H. (2004) Savunma harcamalarını belirleyen faktörler ve ekonomik büyüme etkileri. Ankara Üniversitesi Siyasal Bilgiler Fakültesi Dergisi, 59(1), 159-179.

Granger, C. W. J. (1969). Investigating causal relations by econometric models and cross-spectral methods. Econometrica, 37(3), 424-438. 
Gujarati, D. (2016). Econometrics by example (2.ed). Çeviren: Nasip Bolatoğlu, Örneklerle Ekonometri. Ankara: BB101 Yayınları.

Hou, N., \& Chen, B. (2013). Military expenditure and economic growth in developing countries: evidence from system GMM estimates. Defence and Peace Economics, 24(3), 183-193.

Ismail, S. (2017) Military expenditure and economic growth in South Asian Countries: Emprical evidences. International Journal of Economics and Financial Issues, 7(3), 318-325.

Jabar, M. A., Khalid, M. A., \& Razaq, A. (2015) The impact of military spending on economic growth: Evidence from the US economy. Research Journal of Finance and Accounting, 6(7), 183-190.

Johansen, S. (1988). Statistical analysis of cointegration vectors. Journal of Economic Dynamics and Control, 12(2-3), 231-254.

Kaynak, M. (2014). Kalkınma iktisadı (5.Baskı). Ankara: Gazi Kitabevi.

Kollias, C., \& Paleologou, S. M. (2016). Investment, growth, and defense expenditure in the EU15: Revisiting the nexus using SIPRI's new consistent dataset. Economics of Peace and Security Journal, 11(2), 28-37.

Korkmaz, S. (2015). The effect of military spending on economic growth and uneployment in Mediterranean contries. International Journal of Economics and Financial Issues, 5(1), 273-280.

Lobont, O. R., Glont, O. R., Badea, L., \& Vatavu, S. (2019). Correlation of military expenditures and economic growth: Lessons for Romania. Quality \& Quantity, 53, 2957-2968.

Nargeleçekenler, M., \& Sevüktekin, M. (2010). Ekonometrik zaman serileri analizi: EViews uygulamalı (3. Basım). Ankara: Nobel Yayınları.

Özsağır, A. (2013). Askeri darbe ve müdahalelerin ekonomik performans üzerine etkisi: Türkiye örneği. Gaziantep University Journal of Social Sciences, 12(4), 759-773.

Papanikos, G. T. (2015). Military spending, international trade and economic growth in the Mediterranean Basin. Athens Journal of Mediterranean Studies, 1(2), 187-194.

Pazarlıoğlu, M. V., \& Gülay E. (2007). Net portföy yatırımları Ille reel faiz arasındaki illişki: Türkiye örneği. Dokuz Eylül Üniversitesi i.i.B.F. Dergisi, 9(7), 201-221.

Pesaran, M. H., Shin, Y., \& Smith, R. J. (2001). Bound testing approaches to the analysis of level relationship. Journal of Applied Econometric, 16(3), 289-326.

Phillips, P. C. B., \& Perron, P. (1988). Testing for a unit root in time series regression. Biometrika, 75, 335-346.

Pieroni, L. (2009). Military expenditure and economic growth. Defence and Peace Economics, 20 (4), 327-339.

Soyyiğit Kaya, S. (2013). Türkiye'de savunma harcamalarının iktisadi etkileri üzerine nedensellik analizi (1970-2010). Trakya Üniversitesi Sosyal Bilimler Dergisi, 15(2), 17-38.

Sümer, K. K. (2005). Savunma harcamalarının ekonomik büyüme üzerine etkisinin incelenmesi. Güvenlik Stratejileri Dergisi, 1, 82-91.

Tarı, R. (2010). Ekonometri (6.Baskı). Kocaeli: Umuttepe Yayınları.

The SIPRI Military Expenditure Database (2017). https://www.sipri.org/databases (Erişim Tarihi: 10 Şubat 2019).

Topal, M. H. (2018). Türkiye'de askeri harcamaları ile ekonomik büyüme arasındaki ilişkinin bir analizi (1960-2016). Maliye Dergisi, 174, 175-202.

Topçu, M. K. (2010). Savunma planlamasının ekonomiye etkileri ve savunma bütçeleri. Savunma Bilimleri Dergisi, 9(1), 75-96.

Üçler, G. (2017). Türkiye'de savunma harcamalarının işsizlik üzerine etkisi: 1980-2014 dönemi için ekonometrik bir analiz. Journal of Yasar University, 12(46), 161-170.

Vitali, F. (2018). The role of military expenditures on economic growth in Italy. Journal of Economics Bibliography, 5(3), 175-180.

World Development Indicators. https://databank.worldbank.org/source/world-development-indicators (Erişim Tarihi: 2 Mart 2019).

Yıldırım, J., \& Öcal, N. (2016). Military expenditures, economic growth and spatial spillovers. Defence and Peace Economics, 27(1), 87-104.

Yurttançıkmaz, Z. Ç., Aalı, A., \& Emsen, Ö. S. (2012). Askeri harcamalar ve ambargonun ekonomik büyümeye etkileri: İran üzerine bir uygulama. Atatürk Üniversitesi Iktisadi ve Idari Bilimler Fakültesi Dergisi, 26(2), 171-190. 
This Page Intentionally Left Blank 